粒子としてより単分散粒子に近づけるため，0.3〜0.4 $\mu \mathrm{m}, 0.4 \sim 0.5 \mu \mathrm{m}$ の 2 段として波高值分割を行い， ラ テックス粒子による較正を行った. 検出器は上流側, 下 流側に設け, 測定前に 2 台の器差（ブランクA）をメモ リ一乙上流側濃度 D1，下流側濃度 D2 として $\eta=(1-$ $\mathrm{D} 2 \cdot \mathrm{A} / \mathrm{D} 1) \times 100 \%$ で演算され表示される.吸引量は 0.5 $\sim 2.0 \mathrm{l} / \mathrm{min}$ の籁囲で謂整され, 計測範囲は 1 分間で 1 $\sim 10^{6}$ 個で表示される.予偖的な実験として一般大気, 室 内の粒子数変動叔よび検出器 2 台のブランク值变動範囲 を確認した。一方, 性能については $\mathrm{NaCl}$ を用いた光散 乱濃度法との比較実験を行った. $\mathrm{NaCl}$ の粒子条件は立 方体相当径で約 $0.2 \mu \mathrm{m}$, 標準偏差 1.25 でら材の捕集效 率は檂度 $30 \mathrm{mg} / \mathrm{m}^{3}$ 吸引量 $30 \mathrm{l} / \mathrm{min}$, またマンテスト は浱度 $10 \mathrm{mg} / \mathrm{m}^{3}$ で比較を行った. 大気中の粒子数変 動惊 $0.3 \sim 0.4 \mu \mathrm{m}$ のレンジで $500 \mathrm{cc}$ 中 $10^{4} \sim 10^{6}$ 個で あった．器差 $\mathrm{A}$ の変動は 6 時間の平均值で 1.20, 標準 偏差 1.05 で測定結果への影響はなかった。一方，万材 の捕集效率，マンテスト 10 名の比較については，45 度 に対応して括りマスクの現場管理用として，ろ材のチェ ック，漏れ試験には有効であると思われる。

\section{8. 防じんマスクの保守管理について}

\section{木村菊二 (労研)}

防じんマスクは国家㭘定によって，その性能が保証さ 机ている。しかし，そ机は防じんマスク自身のことであ って，マスクが適正に使用されなければ，その性能を発 揮させることはできない。

前報に括いて着用者の顔に合った防じんマスクの選択 方法, 渎用にとるなう性能の变化などについて報告し た。本報て棌守管理に関連して，万過材の手入の方法 とその交換時期などに関する検討の結果を報告する.

現在，市販されている，注とんどの防じんマスクのる 過材には静電ろ層が使用されている。そこで，ここでは 扣もに静電ら畨の保守管理について述べる.

1）万過材に付着した粉じんの除去方法

ろ過材に付着した粉じんを除去する方法としては，ろ 過材を持って軽くたたくのがよい，強くたたいたり，压 維空気の嘪射を用いて付着した粉じんを吹飛ばしたり， また水洗いしたりすることは，ろ過材を傷めてしまらこ とがあるので禁物である。

2) 万過材の交換時期

ろ過材理使用することによって，その性能が変化す る.すなわち粉じんを捕集することによって目づまりを 生じ，吸気抵抗が上昇し，またろ層に粉じんが付着する ことによって捕集效率が低下することもある，乙かし幾 つかの工場に和ける調查結果を総合してみると，万過材
の使用時間，吸気抵抗，粉じえ捕集効率の間には一定の 関係は認められない，この原因は暴露する粉じんの種類 や濃度，手入れの方法などの違いによるものと推定され る.

以上のような結果から， 万過材を交換する基準は，ろ 過材の性能の低下, すなわち吸気抵抗の増加と粉じん捕 集効率の低下を目安に決めるのが適切であるうと考光 る.

\section{座長のまとめ $(107,108)$}

\section{本間克典（産医研）}

107 : 防じんマスクの滤過捕集率は粉じんの粒径飞大 きく依存するが，測定に際して単分散の粉じんを容易に 発生しにくいため，粒径別捕集率に関する情報を得るの はきわめて困難である、ところで，本論文は環気中粉じ んを対象として，粒径別の光散乱強度を測定する手法を 応用し，粒径別捕集率を求める方法について述べてお り，防じんマスクテスターとして簡便に使用できること から，粒径別捕集特性の把握渏与する之考克られる.

108 : 防じんマスクの保守管理はきわめて重要である が，十分に徹底しえないのが寒状である，演者は保守管 理状沅の異なる溶接作業使布されたマスクについて, 吸気抵抗と捕集率の関係から，現在広く使用されている 静電濾層式の場合，吸気抵抗が $8 \mathrm{mmH}_{2} \mathrm{O}$ を超光たも のまを捕集率が $95 \%$ 未満となったものは再度使用乙 ないことを提唱している．乙かし，捕集率の現場測定が 容易に行い兄ない現状では，さらに簡単な目安を与兄る ことが望まれる。

\section{9. 人肺組織中沈着粉塵の $X$ 線微小分析のための試 料処理法の比較}

京野洋子, 神山宣彦（産医研）

少量の人肺組織で沈着粉麼の組織反応を調べかつ元素 分析を行らために，従来（A）パラフィン包埋肺組織の $4 \mu \mathrm{m}$ 厚切片を, グラファイト膜にのせ脱パラ後炭素蒸 着し，走查電顕観察とX線微小分析用試料として用いて きた．万法が簡便で光顕組織像との対応がよい反面， submicron 粒子や微細アスベスト繊維などの識別が困 難で定量性も不足していた，その欠点を補うため，（B） 同一試料の連続切片を，低温兏化後粉麼残淩のカーボン 抽出試料，(C) 同組織の一部をグルタルアルデヒド再固 定エポン包埋超薄切片試料，として分析電顕による観察 とX線微小分析を行い結果を椙互比較した。

クロム肺癌手術組織と溶接工肺を例示した。 $\mathrm{Cr}$ 酸塩 製造工程に 30 40 年従事後発症した肺癌手術組織の粉 栕沈着部位で，試料(A) では，クロマイト（不純物 $\mathrm{Mg}$ ， $\mathrm{Al}, \mathrm{Si}$ 含む) や雲母鉱物等を認めた。試料(B)では 